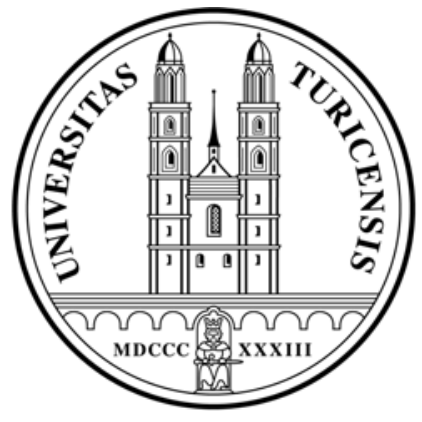

Institute for Empirical Research in Economics

University of Zurich

Working Paper Series

ISSN 1424-0459

Published in: Journal of Economic Behavior and Organization 54. 65-88. (2004)

Title: Pro-Social Behavior in a Natural Setting.

Working Paper No. 107

Pro-Social Behavior, Reciprocity or Both?

Bruno S. Frey and Stephan Meier

February 2002 


\title{
Pro-Social Behavior, Reciprocity or Both?
}

\author{
BRUNO S. FREY
}

STEPHAN MEIER *

This draft: 21 January 2002

\begin{abstract}
Empirical evidence is provided for the importance of non-reciprocal pro-social behavior of individuals in an anonymous, n-person pure public good setting. A unique panel data set of 136,000 observations is matched with an extensive survey.

Even under anonymous conditions, a large number of individuals are prepared to donate a not insignificant sum of money. Cooperation conditional on giving by specific other persons (reciprocity) is present but the causal relationship is ambiguous. It is crucially important, whether, and in what way, one is asked to donate. Identification with the organization is also important.
\end{abstract}

Keywords: Public Goods, Pro-social behavior, Reciprocity, Donation

JEL classification: H41, D64, Z13

\section{Beyond Self-Interest}

Assuming that the behavior of human beings is driven by self-interest has been a powerful approach when studying the economy. The self-interest hypothesis predicts individuals choices pretty well in most competitive markets. This also holds for most types of behavior outside the traditional economic markets. "Economic imperialism" or, more generally, rational choice analysis, which builds on the self-interest assumption, has had great success in

\footnotetext{
* Bruno S. Frey is Professor of Economics, and Stephan Meier is Research Assistant, at the Institute for Empirical Economic Research of the University of Zurich. Bluemlisalpstrasse 10, CH- 8006 Zürich, Switzerland; Phone: ++41-1-634 37 28, Fax:++41-1-634 49 07, e-mail: bsfrey@iew.unizh.ch, smeier@iew.unizh.ch.
} 
many areas outside of economics, examples being politics, history, law, the arts, or the family (e.g. Becker 1976, 1996, Stigler 1984, Frey 1999, Lazear 2000).

But not all applications of the self-interest hypothesis meet the necessary conditions under which it works well; many markets are characterized by rigidities, incomplete contracts, or by a small number of traders. Warnings have been issued that the application of the calculus of self-interest may face decreasing marginal returns (e.g. Hirshleifer 1985, Frey 2001). A recent book on giving and altruism, appearing under the auspices of the International Economic Association, even understands itself as an "obituary of Homo oeconomicus" (Kolm 2000a: 32). Studies of important activities, such as charitable giving (e.g. Andreoni 1990, 1998, Weisbrod 1998), voting (e.g. Mueller 1989, 1997), and tax paying (e.g. Slemrod 1992, Andreoni, Erard and Feinstein 1998) have convincingly argued that such actions cannot be explained by relying on the strict self-interest axiom. Thus, for example, it has been stated that "[A] purely economic analysis of the evasion gamble implies that most individuals would evade if they are "rational", because it is unlikely that cheaters will be caught and penalised" (Alm, McClelland and Schulze 1992:22; similarly Graetz and Wilde 1985:358, Skinner and Slemrod 1985). But most people actually pay their tax dues. Tax payment can therefore be considered a "quasi-voluntary act" (Levi 1988). The self-interest model has been clearly rejected in a great number of laboratory experiments (see Fehr and Schmidt 1999, Fehr and Gächter 2000). Most importantly, experiments of the Ultimatum Game in 15 societies exhibiting a wide variety of economic and cultural conditions reveal that "the canonical model of the self-interested material pay-off maximizing actor is systematically violated" (Henrich et al. 2001: 77).

As a result of these findings, the reciprocity model has recently gained much attention. Reciprocity occurs when persons act in a more cooperative manner as a response to the friendly behavior of others and act in a hostile way when treated in an unfriendly way by others. It has been claimed that " Practically all life in society includes and implies reciprocities, and reciprocity has been seen as the basic glue that makes people constitute groups or societies" (Kolm 2000b: 115). Recently, a large number of laboratory experiments have been devoted to the study of reciprocity in economics (see the surveys in e.g. Fehr and Gächter 2000, Fehr and Schmidt 2000, Gächter and Falk 2001, Falk and Fischbacher 2001). It supplements evidence that has been provided for decades by anthropology (e.g. Mauss 1924, Sahlins 1970, Godelier 2000), by sociology and social psychology (e.g. Gouldner 1960, Adam 1963, 1965) as well as by economics itself (early contributions are Boulding 1973, Kolm 1973, 1984, Collard 1978). But the emphasis on reciprocity comes at a price. Forms of 
pro-social preferences not implying reciprocity are often neglected in theoretical as well as empirical analyses. This paper argues that there is very important pro-social behavior that goas beyond reciprocity. People are prepared to act in a non-selfish, altruistic and nonstrategic way and - above all - such behavior is contingent on environmental and institutional conditions.

This paper provides empirical evidence for the importance of non-reciprocal pro-social behavior of individuals in an anonymous, $n$-person pure public good setting. We use a unique panel data set of 136,000 observations (roughly 33,000 persons) concerning the decisions of students at the University of Zurich on whether or not to contribute to two Social Funds administered by the University. These field observations are matched with an extensive survey of the same group of people to find out more about the conditions and motives for giving.

We are able to show that even under these anonymous conditions, a large number of individuals are prepared to donate a not insignificant sum of money. This finding is not trivial; it contradicts for instance the statement that "Positive and stable contributions to the public good are very unlikely ... free riding will be pervasive under conditions of anonymous interactions" (Fischbacher, Gächter and Fehr 2000: 9). We identify evidence of indirect reciprocity: when students expect that others also contribute, they themselves tend to donate more, but of course the direction of causality is not at all clear, i.e. one's own willingness to donate may lead one to expect that others behave in the same way. ${ }^{1}$ Moreover, due to complete anonymity, the individuals in our sample do not know what the others are doing and seem not to be interested in knowing. While cooperation that is conditional on giving by specific other persons is present but ambiguous, the donations are contingent on the environmental and institutional conditions under which the donations take place. In particular, it is crucially important whether, and in what way, one is asked to donate. The behavior of the students seems to indicate that not only the way the question is framed is vital but also that identification with the organization is an important institutional condition which influences their pro-social behavior.

Finally, our data suggests that individuals differ in the extent of their pro-social preferences. To a certain extent they self-select according to their own preferences for the different disciplines (faculties) taught at the university. A novel result in this context is the impact of

\footnotetext{
${ }^{1}$ For a discussion of the so-called 'false consensus' effect see Ross et al. 1977 and Dawes et al. 1977.
} 
teaching, i.e. whether giving is influenced by what professors teach in class about the rationality of contributing to public goods.

Section II discusses the concept of reciprocity in the context of giving behavior and confronts it with pro-social behavior. On that basis, theoretical hypotheses are derived. The following section III presents the actual case studied and the data collected. The econometric analysis to test the hypotheses is undertaken in section IV. The last section V offers conclusions.

\section{Reciprocity and More General Pro-Social Behavior}

The effect of reciprocity on giving for the voluntary funding of a (linear) pure public good (which is both non-rival and non-excludable) can be analyzed in the following way (e.g. Croson 1996): Each potential contributor $i$ in the group of $n$ identical persons involved has an income $Y_{i}$, which she can either use to donate to a fund $F$ or to consume private goods. If $d_{i}$ is the contribution to the fund, the individual is privately able to consume $Y_{i}-d_{i}$. The individual's earning from the fund is a multiple ${ }^{2} \mathrm{~m}$ of the sum of donations from all the participants, $m d_{i}$. A public good problem exists whenever $1 / n<m<1$. When $m<1$, it is never optimal for a self-interested person to contribute to the public good because the contribution costs her one unit but earns her only $\mathrm{m}$. When $1 / \mathrm{n}<\mathrm{m}$, contributing to the public good is always optimal for the group as a whole, because donating one unit to the public good costs the individual one unit but earns $\mathrm{n} * \mathrm{~m}$ for the group.

For selfish individuals, there is a unique dominant strategy equilibrium in which all persons in the group free ride (i.e. contribute nothing), independent of what the others do. If, however, an individual's utility function depends on another individual's (or group of individuals') utility (Becker 1974), a higher contribution by the other members to the fund induces a reduction in the individual's own contribution (Sugden 1982). If an individual's utility moreover positively depends on the amount she contributes (Andreoni’s 1989, 1990 “warm glow of giving"), her donation and the contributions by the others are imperfect substitutes. The reduction in the individual's contribution is smaller than in the case of Becker's pure altruism. In the context of the public goods model, Sugden (1984) formalizes reciprocity by assuming that an individual contributes the minimum of (i) the smallest donation of all other group members and (ii) the donation level she would most prefer other group members to

\footnotetext{
${ }^{2}$ The multiple $\mathrm{m}$ is the marginal return for each individual when he or she contributes one unit to the fund.
} 
make. It follows that there may be a positive correlation between the donation of a particular person and the contributions by the other members. This result is consistent with reciprocity in a one-shot equilibrium context. A more general theory of reciprocity has been advanced by Rabin (1993). Reciprocity is defined as the desire to be kind to those who are perceived to behave kindly towards you, and to punish those who are perceived to act in a hostile way towards you. This theory, which bases reciprocity on intentions ${ }^{3}$, again predicts that a person donates more if the others contribute too (see also Dufwenberg and Kirchsteiger 1999, Falk and Fischbacher 2001).

Depending on the issue to be analyzed, there are many reciprocity concepts ${ }^{4}$. In the context of our study, the idea of conditionality in the reciprocity concept is crucial. Individuals are defined to be conditional cooperators when the positive correlation discussed above obtains, i.e. when people contribute the more to a public good, the more the others contribute ${ }^{5}$. In a recent standard public good experiment, for example, it was identified that, according to this definition, roughly 50 percent of the subjects are conditional cooperators while a third of the subjects act as free riders (Fischbacher, Gächter and Fehr 2001).

This study argues that there are important cases in which this kind of conditional reciprocity cannot solely explain the substantial share of individuals willing to contribute to the public good. This non-reciprocal giving will be called "pro-social behavior". While it is not conditional on the contribution of others (type I conditionality), it strongly depends on another kind of conditionality (type II conditionality), namely the environmental and institutional conditions under which the contributions take place. Several studies support type II conditionality in a specific sense: Being asked is an important factor in explaining why people contribute to a public good and offer voluntary work (Varese and Yaish 2000; Opp 2001: 3-5; Freeman 1997; Foster et al. 2001). In addition to being asked, pro-social behavior also depends on the way one is asked. Although the decision remains the same, the institutional change has significant behavioral consequences. This context dependence has been labeled 'institutional framing' by Isaac et al. (1991). This is consistent with findings in Ultimatum Game experiments that have been conducted in 15 cultures: “... the preferences

\footnotetext{
${ }^{3}$ Because intentions are crucial, this reciprocity model differs from fairness models, where the behavioral responses are solely caused by inequity aversion (Bolton and Ockenfels 2000, Fehr and Schmidt 1999).

${ }^{4}$ For example, direct and indirect, strong and weak, chain and general reciprocity (see e.g. Bowles and Gintis 2001, Kolm 2000b).

${ }^{5}$ See e.g. the experiments by Keser and van Winden 2000, Sonnemans, Schram and Offerman 1999, Croson 1998.
} 
over economic choices ... are shaped by the economic and social interactions of everyday life" (Henrichs et al. 2001:77). This indicates that outside the lab, conditionality of type II is crucially important.

Pro-social behavior varies considerably between individuals. While some persons act according to the economic assumption and therefore free-ride in social dilemma situations, others reveal substantial pro-social preferences. According to these differences, individuals select into specific groups. As has been shown by prior studies, economists seem to constitute one such group (e.g. Carter and Irons 1991 and Frank et al. 1993). It is thus crucial to analyze such differences - between economists and non-economists - outside the lab. Especially if one is interested in whether economics training destroys pro-social behavior, one should look at behavior in a natural setting.

On the basis of this discussion, we advance the following hypotheses for the case of contributing to a social fund:

H1: A substantial number of people are prepared to act in a pro-social way in an anonymous situation - even after several rounds.

H2: Expectations about the contributions of other people matter. The more people expect others to cooperate, the more they cooperate themselves (Conditionality of type I).

H3: The environment under which the donations take place matters (Conditionality of type II). In particular, it is essential that people are asked to contribute in a way they perceive as acceptable.

H4: People differ in their pro-social attitudes. The type of person (as reflected in part by their choice of study) influences donating even when standard personal characteristics (gender, and age) are controlled for.

H5: Teachers have no influence on who donates and who does not donate.

In the following sections, we test these hypotheses empirically.

\section{The Empirical Case and the Data}

Each semester, all the students at the University of Zurich have to decide whether or not they want to contribute to two official Social Funds - in addition to the compulsory tuition fee. On the official letter for renewing their registration, the students are asked whether they want to 
voluntarily give a specific amount of money (CHF 7.-, about US\$ 4.20) to a fund which offers cheap loans to students in financial need and/or a specific amount of money (CHF 5.-, about US\$ 3) to a second fund supporting foreigners who study at the University of Zurich. Without their explicit consent (by marking a box), students do not contribute to any fund at all. Our data refers to the decisions made in the seven semesters from the winter semester 1998/99 up to and including the winter semester $2001 / 2002$. The fact that every student at the University of Zurich has to decide anew each semester whether he or she is willing to contribute to one or both of the Social Funds generates a large number of observations. Table 1 presents summary statistics of the data set. The table also shows the amount of students who contribute to at least one of the funds for each variable. We observe the decisions of 32,961 students who decide on an average 5.4 times, depending on how many semesters they are there. The decisions from the seven semesters are pooled, generating 136,862 observations. The panel structure allows us to analyze the effect of repetition on the decision to contribute. As well as that, we have aggregated data since 1993, which allows us to test the effects of environmental and institutional conditions on giving behavior.

In addition, an anonymous on-line survey among the same student group of the University of Zurich was undertaken. ${ }^{6}$ The response rate was 18 percent. From this sample, we were able to use 3'256 answers, containing responses to all the questions relevant for our context. This sample is not totally representative (not surprisingly, a larger number of economics students responded to the questionnaire sent out by two economists), but with respect to gender and age, the sample corresponds to the distribution of students at the University of Zurich. The survey again asked whether the person contributed money to one or both of the funds. 73 percent responded that they did, compared to the 68 percent who actually contributed. This difference between survey answers and actual behavior is found in a lot of survey-based studies. While the differences can be the result of people lying (see Eichenberger and Oberholzer-Gee (1998) for differences between hypothetical and real decisions), a more convincing explanation is that people who contributed to the Funds are more likely to respond. The differences should be kept in mind while interpreting the survey data.

The donations by the students to the Social Funds have three important characteristics:

(1) A large number of people are involved (more than 33,000 people). The condition $1 / \mathrm{n}<\mathrm{m}$ is certainly fulfilled and rational selfish individuals would not contribute to the fund.

\footnotetext{
${ }^{6}$ The on-line questionnaire is reproduced at http://www.iew.unizh.ch/grp/frey/fragebogen.htm.
} 
(2) It is not generally known who receives actual support from the funds.

(3) Whether a student donates or not to the Social Funds remains completely anonymous. Social pressure can therefore be excluded as a motive.

As will be explained in detail in the next section, these characteristics exclude direct reciprocity as defined above. Donations to the Social Funds at the University of Zurich are therefore more a case of pro-social behavior.

\section{Analysis and Results}

\section{Pro-social behavior}

The raw data suggest that the students in our sample do not act like the traditional economic model of selfish individuals that it predicts. A large proportion of the students are prepared to contribute to the funds. Between the years 1998 - 2001, on average more than $68 \%$ of the individuals contributed to at least one of the funds (see table 2). More than $61 \%$ contributed to both funds. ${ }^{7}$

\section{TABLE 2 ABOUT HERE.}

As the decision is not a laboratory dictator or public good game, we can exclude that prosocial behavior is due to an experimenter effect or some other sort of direct reciprocal reaction mentioned by Hoffman et al. (1996). They believe that the fact that anonymity is not completely guaranteed can indeed explain the remaining level of donation in their dictator game. Johannesson and Persson (2000), on the other hand, by increasing social distance between dictator and recipients even more, find evidence of non-reciprocal altruism. In our case, the students decide at home and under totally anonymous conditions. So, direct reciprocity either (i) by the students and/or (ii) by the University can be ruled out as an explanation of the contribution, as will be explained in detail below.

(i) Students who do not contribute to the funds cannot be punished or accused of being selfish by their colleagues. The mechanism of punishment for sustaining cooperation, discussed e.g. by Fehr and Gächter (2000), cannot explain the high number of people acting pro-socially. In

\footnotetext{
${ }^{7}$ In dictator games, the contribution of the subjects is much lower. These differences can be explained by the fact that recipients differ. Eckel and Grossman (1996) show in an anonymous dictator game that contributions are much bigger if the subjects can give money to an established charity rather than another student.
} 
the absence of any form of punishment, one would expect that repetition strongly decreases cooperation, as shown by public goods experiments (Dawes and Thaler 1988, Ledyard 1995, Fehr and Gächter 2000). Figure 1 shows the willingness to give money to the Social Funds to be dependent on the number of semesters the students study at the University. The repetition of the decision only weakly decreases the level of contribution. This observation supports the idea that in the situation analyzed, direct reciprocity activated through a punishment mechanism is not necessary in order to sustain the pro-social behavior of the students. However, the sustainability of contributions under anonymity cannot exclude indirect reciprocity ('conditional cooperation'). We will test this notion in the next section.

(ii) Direct reciprocity on behalf of the University is also excluded. The contribution of the students does not influence any possible future support from the funds in case of need, nor does it in any way affect the relationship between the students and the University.

\section{FIGURE 1 ABOUT HERE.}

The results of the descriptive statistics are consistent with hypothesis 1: even after several rounds, a large number of students act pro-socially in an anonymous decision setting. Because no mechanism of punishment and therefore direct reciprocity is at hand, this result supports the existence of non-reciprocal pro-social preferences. Conditional cooperation cannot be excluded from the evidence presented. In the following sections we analyze whether this indirect type of reciprocity can explain the contribution of the students to the funds.

\section{Indications of indirect reciprocity}

Theories of reciprocity suggest that people contribute to a public good dependent on the behavior of others. Individuals dislike being a so-called 'sucker', i.e. being the only one who contributes to a public good while the others free-ride. The more one thinks that others cooperate, the greater is the probability that this person contributes him- or herself. To test this notion, the students were asked via a large-scale online survey, how many other students they expect to be contributing. The results of our survey show that expectations about others correlate with the individual decision to contribute to the Social Funds. The coefficient of the correlation between the expressed expectation and the contribution to at least one fund is 0.34 . This correlation is quite large and statistically significant at a 99\%-level $\left(\mathrm{F}_{1,3168}=415.47\right.$, $\mathrm{p}>0.01$ )and. As can be seen from Figure 2, the marginal effect is substantial. ${ }^{8}$ An increase of

\footnotetext{
${ }^{8}$ The marginal effect vector in a probit analysis equals 0.0062 (s.e. 0.00035).
} 
the perceived cooperation of others by 10 percentage points increases the individual probability of contributing by 6 percentage points.

\section{FIGURE 2}

But the causality is not at all clear. While for the notion of conditional cooperation it is important that individuals cooperate conditional on the behavior of others, the causality can be the other way around: people who behave in a cooperative way also expect others to cooperate. They deduce from their own behavior how they think other people will behave. The perceived expectation about the cooperation of others is therefore a good indicator of people's own pro-social behavior and not evidence for conditionality of type I. Similarly, Glaeser et al. (2000) found evidence of such an effect in their study about trust and conclude: '... the best way to determine whether or not a person is trustworthy is to ask him whether or not he trusts others'. This problem of causality gets even more obvious if one looks at how little students really know about the real contribution rate.

Students do not know for certain what others do and also do not seem to be interested in the behavior of the others, as they don't talk with their colleagues about the two Social Funds.

\section{TABLE 3 ABOUT HERE.}

Table 3 shows the answers to two questions designed to find out whether the students are aware of the behavior of others and whether they actually talk with each other about the Funds. The results indicate that more than three quarters of the students do not tell their friends whether they contributed or not. Three quarters of the students never talk with their colleagues about the funds. These results throw even more doubt on the notion that the causality of the correlation goes from the expectations about the share of contributions to one's own contribution.

The results of the empirical analysis are consistent with hypothesis 1 and also partly apply for hypothesis 2. A large number of students behave pro-socially. The anonymous situation does not allow for direct reciprocity. But there is empirical support that students do compare with others and that their actions depend on the behavior of others. The evidence for this indirect reciprocity in the form of conditional cooperation (Conditionality of type I) is ambiguous. While the correlation between the expected cooperation rate and the actual contribution of the students is quite big, the causality is more than unclear. Only approximately every fifth student knows the behavior of her colleagues or talks with others to find out about the appropriateness of their own behavior. We conclude that students behave pro-socially not 
exclusively conditionally on the behavior of others. Pro-social behavior depends more on the environmental and institutional conditions, as will be argued in the next section.

\section{Pro-social behavior depends on Environmental and Institutional Conditions}

We have adduced empirical evidence that contributing to the two Social Funds is not only due to reciprocal considerations but to other pro-social attitudes. This pro-social behavior depends on institutional conditions. A crucial institutional feature supporting pro-social behavior is being asked to do so. Moreover, it very much depends on how one is asked. Different ways of framing the same question institutionally can change the prevalence of pro-social behavior dramatically (for framing effects see e.g. Quattrone and Tversky 1988, Lindenberg 1992 , Sonnemans et al. 1998, Andreoni 1992 and Elliott and Hayward 1998).

At the University of Zurich, an exogenous variation of the institutional conditions allows us to test the effect on pro-social behavior. Due to a restructuring of the administration, the University of Zurich changed the official letter for renewing students' registration for the winter term in 1998. After this semester term, the administration was able to handle students' decisions electronically. The students are now asked to contribute in the following way: they have to tick boxes to decide if they want to donate money to one or the other, to both or to none of the Funds. After a month, they receive an invoice with the compulsory tuition fee plus the chosen amount for the Social Funds. Before the winter term 1998, students received two invoices and had to chose between the two; one with the amount of the compulsory tuition fee on it, and the other with the amount of the tuition fee plus the amount due for contributions to both Funds.

Figure 3 shows the effect of the exogenous change in the institutional setting on pro-social behavior. After the change effected in the summer term 1998, the percentage of people contributing to the two Social Funds increased from an average of $44 \%$ to $62 \%$. The difference is statistically significant (t-test of differences of distribution: $t$-value $=-11.1$ ). Moreover, according to the new system, the students can also opt for only one of the funds, so the percentage of people who contribute to at least one of the funds saw an even bigger increase. This result is consistent with hypothesis 3 that pro-social behavior is sensitive to changes in the institutional conditions.

FIGURE 3 ABOUT HERE. 
Standard economic reasoning would consider the two decisions identical, because the underlying decision to be taken is the same: does one want to contribute money to the two Funds or not? And the prediction is also straightforward: no homo oeconomicus will donate any money in either of the two anonymous decision settings. But even for non-traditional explanations of cooperative behavior (e.g. reciprocity and pure altruism), the different settings should not affect the behavior of the subjects. If, for example, cooperation is only conditional on the behavior of others, no behavioral difference should be observed in the two settings. Thus, it is obvious that our theory must go beyond an assumption of reciprocity or pure altruism because they are unable to explain the results presented here. However, the concept of pro-social behavior, as presented above, depends on the institutional conditions or the context of the decision. ${ }^{9}$

The context dependent pro-social behavior has been labeled 'institutional framing' by Isaac et al (1991). Frey and Bohnet (1995) and Bohnet and Frey (1999) further developed the idea and present evidence that institutions affect fairness consideration in experiments. They allow for one-way identification in a dictator game and observe that the amount shared increases substantially. Their analysis indicates the importance of identification with the "victim" ${ }^{\prime 10}$. The increase seems to support the concept of context dependent pro-social behavior, which goes beyond reciprocity and pure altruism. The same holds for identification with an organization. As has been shown in other studies, especially in studies concerning alumni giving to universities, attachment to an organization is an important factor in explaining pro-social behavior (Clotfelter 2001, Mael and Ashforth 1992). In the case of the contribution to the two social funds of the University of Zurich, changes in the institutional conditions which affect the identification with the University, should explain some of the variation in giving behavior.

One such change in the environmental and institutional conditions takes place at the beginning and the end of a student's University life. For both periods, students' physical attendance at the University is lower than in the periods in between. Before taking up their studies, i.e. at the very beginning, students obviously have not attended the University at all; at the end of their studies, students no longer attend classes but prepare for their exams over an extended period (more than half a year in the Swiss University system) and therefore

\footnotetext{
${ }^{9}$ Andreoni (1992) presents evidence that positive framing leads to more cooperation in a public good experiment than negative framing of the same decision. He explains this difference in the light of the 'warm glow' effect. '(...) it must be that people enjoy doing a good deed more than they enjoy not doing a bad deed'(p. 11).

${ }^{10}$ The idea of the so-called 'identifiable victim effect' goes back to Schelling (1968) and has recently been analyzed by Jenni and Loewenstein (1997).
} 
attend the University only sporadically. The strongest identification with one's University should exist when students regularly attend courses and feel themselves to be a part of the student body and of their alma mater. As a consequence, students are expected to contribute significantly less to the Social Funds at the beginning and end of their studies.

The first decision of whether to contribute to the Funds is taken before the students are actually attending the University. They are registered, but the actual decision concerning their contribution takes place before the start of the freshman semester. Again, the traditional economic prediction would not change. But as can been seen from a probit model, estimated for the period 1998-2001 and reproduced in table 4, this change in environmental condition systematically affects behavior. The probability that a first semester student contributes money is 2.3 percentage points lower compared to those in the following semesters (the reference period is the basic study). This effect is statistically significant at the $99 \%$-level and persists in an estimation with personal fixed-effects (see the conditional logit model in table 4).

\section{TABLE 4 ABOUT HERE.}

The effect on contributing while being in the last semester is also shown in table 4. The variable for the last semester takes the value 1 if a student is in her last semester and 0 otherwise. Both models show a significant effect for being in the last semester. The probability of contributing to at least one fund decreases 6.6 percentage points compared to the preceding periods.

The two behavioral regularities observed - that students tend to contribute less before they start their studies, and at the very end of their studies - is consistent with a changing identification with the University as an organization.

The control variables show the expected signs: the different stages in a student's studies (Main stage and Ph.D.) do not have a significant effect on his or her pro-social behavior in the fixed-effects estimation which controls for individual heterogeneity. As could already be seen in the descriptive statistics, the Number of semesters decreases the probability of a contribution to the Funds. Gender does not have an effect on giving behavior. In contrast, Married students are more generous than their single colleagues. However, the effect is not statistically significant in a fixed-effects model. Marriage itself does not make one more generous, but married students are a special selection. Over time, the willingness to contribute increases as indicated by the period dummies. Interestingly, the probability that foreign 
students contribute to the Social Funds is smaller than for Swiss students. This behavior of foreign students is of interest because one of the two Funds is exclusively designed to support foreigners. It could be that, if foreigners contribute they tend to prefer to support other foreigners.

Table 5 shows the descriptive statistics for the contributions of foreigners to the Social Funds. Foreign students, to the extent they contribute at all, mainly have a tendency to support other foreigners. The result is supported in a multinominal regression model which includes control variables. This pattern of pro-social behavior can be interpreted as further support for the importance of identification for giving. Foreigners feel more identified with other foreigners. This evidence is consistent with various studies, which find that group identity explains a lot about pro-social behavior (Simon 1993, Dawes and Thaler 1988, Turner and Giles 1981, Akerlof and Kranton 2000). In contrast to these experiments, where group identity is achieved through discussion, our data suggest that even anonymous group attachment can evolve.

\section{TABLE 5 ABOUT HERE}

The empirical results in this section show that pro-social behavior depends on environmental and institutional conditions (hypothesis 3). Most of all, the way one is asked to contribute to a public good is of great importance, even in the absence of personal contact. Moreover, our results support the crucial effect of identification and identity for giving behavior.

\section{Effect of Education on Pro-Social Behavior}

People seem to differ in their pro-social preferences, which leads to different behavior as, for example, is reflected in experimental settings (e.g. Fehr and Gächter 2000, Weimann 1994). Some of them free-ride right from the beginning of the game and thus behave according to the standard economic predictions, while others deviate from this prediction substantially and act in a pro-social way. We test this notion about different types of persons in our data set (hypothesis 4) by looking at potential selection effects. People with similar preferences select themselves into similar subjects at the University. If this is the case, we should observe that the distribution of selfish types is not random, but systematic. ${ }^{11}$ To test this hypothesis, we look at the very first decision to contribute to the two Funds at the University. At this date

\footnotetext{
${ }^{11}$ Similarly, Ockenfels and Weinmann (1999) compare the preferences of East- and West-Germans in laboratory experiments and find differences in their cooperative behavior. Cadsby and Maynes (1998) compared the behavior of nurses with economics students in an experimental public good game.
} 
time students have not yet attended any lectures at the University, so we can exclude any effects resulting from the influence of University training.

While $73 \%$ of arts students contribute to the Funds, only $64 \%$ of law students do so. ${ }^{12}$ The chosen discipline of study partially reflects the type of students and their behavior, which is consistent with hypothesis 4 . Because the students of the faculties could differ systematically with regard to other characteristics, such as sex or age, which correlate with giving behavior, we estimate a multivariate regression model. The results in table 6 support our hypothesis that students differ in their social preferences and select according to these preferences into different subjects. The control variables in this estimation for students in their first semester show the same effects as in table 4. An exception is the behavior of women. Counting all the semesters, women do not behave significantly differently from men, but the probability that women contribute to the funds is almost 4 percentage points lower in the first semester than it is for men. This result contradicts previous results of behavioral differences between women and men (Eckel and Grossman 1998, Ortmann and Tichy 2000). Further research should investigate which conditions in the data set used influence the behavior of the two sexes (for similar experiments, see Andreoni and Vesterlund 2001).

To test whether pro-social preferences are influenced by education, we consider students who are extremely exposed to 'indoctrination' effects: economics students. A lot of critics of economic imperialism believe that studying economics changes cooperative behavior (Ostrom 1998, Kelman 1987). Therefore, we test whether economics students adapt to the predictions of learned (conventional) theory, and whether it is taken as normative advice with respect to pro-social behavior. Prior research has looked at the differences between economists and noneconomists in their cooperative behavior (e.g. Marwell and Ames 1981, Carter and Iron 1991, Frey et al. 1993 and Frank and Schulze 2000). Especially Frank et al. (1993, 1996) identified behavioral differences in Ultimatum games between economists and non-economists. Moreover, they found that training in economic theory changes the willingness to behave prosocially for the economics students. We call this the indoctrination hypothesis and test it with our data of the University of Zurich. ${ }^{13}$

As can be seen in table 6 , the behavior of students of different disciplines is mostly due to selectivity effects. Even before attending the first lecture, differences in pro-social behavior

\footnotetext{
${ }^{12}$ The respective results for students of other faculties are: $77 \%$ of students of theology, $65 \%$ of medical students, $58 \%$ of veterinary medicine students and $67 \%$ of natural science students contribute to at least one fund.
} 
exist. Not only economics, but also subjects like law tend to attract selfish students. If economic theory influences the cooperative behavior of economics students negatively, we should expect the differences between economists and non-economists to widen over time. To test whether these behavioral differences do indeed increase over time, we estimate a conditional logit model with personal fixed effects. With this model, we control for individual heterogeneity. We use interaction terms (such as Economists ${ }^{*}$ Number of Semesters) as proxies for economic indoctrination. Table 7 presents the respective results. The results support hypothesis 5: teaching economic theory does not influence giving and cooperative behavior. For economics students, who are exposed to a rather extreme theory of human behavior, the willingness to contribute does not decrease in a statistically significant way. Compared with other students, only students of law, medicine and veterinary medicine negatively change their behavior during their study. Interestingly, for students of theology the willingness to contribute increases during their studies. Whether this is the effect of religion is questionable and lies outside the scope of this paper. ${ }^{14}$

To summarize, our results show that students select into different disciplines of study according to differences in their pro-social preferences. Furthermore, economics students are not influenced by teaching where pro-social behavior is concerned. Economics students do not change their pro-social attitudes as a result of their economics training. The results are consistent with hypotheses 4 and 5.

\section{Conclusions}

This paper has provided empirical evidence for the importance of non-reciprocal pro-social behavior of individuals in an anonymous, n-person pure public good setting. We use a unique panel data set of 136,000 observations (roughly 33,000 persons) concerning the decisions of students at the University of Zurich to contribute to two Social Funds administered by the University. These field observations are matched with an extensive survey of the same sample group of students to find out more about the conditions and motives for giving.

Four hypotheses are tested with these data:

\footnotetext{
${ }^{13}$ For an extensive test of the differences between economists and non-economists, see Frey and Meier (2001).

${ }^{14}$ The influence of religion on the contribution to public goods is discussed in Lipford, McCormick and Tollison (1993) and Hull and Bold (1995).
} 
1: A substantial number of people are prepared to act in a pro-social way in an anonymous situation in which direct reciprocity is absent.

The results of the statistics are consistent with hypothesis 1: Even after several rounds, a large number of students act pro-socially in an anonymous decision setting. Because no mechanism of punishment and therefore direct reciprocity is at hand, this result supports the existence of non-reciprocal pro-social preferences. But conditional cooperation cannot be excluded by the evidence presented.

2: Expectations about the contributions of other people matter. The more people expect others to cooperate, the more they cooperate themselves (conditionality of type I).

The results of the empirical analysis are consistent with this hypothesis. While the anonymous situation does not allow for direct reciprocity, students compare themselves with others and make their actions dependent on their expected behavior of others. The evidence for this indirect reciprocity, in the form of conditional cooperation, is ambiguous. While the correlation between the expected cooperation rate and the actual contribution of the students is quite big, the causality is unclear. Only approximately every fifth student knows the behavior of his or her colleagues or talks with others to find out about the appropriateness of their own behavior. Students thus seem to behave pro-socially but not exclusively conditional on the behavior of others.

3: The environment under which the donations take place matter (conditionality of type II). In particular, it is essential that people are asked to contribute in a way they conceive to be acceptable.

The empirical results suggest that pro-social behavior depends on environmental and institutional conditions. The way one is asked to contribute to a public good is of great importance, even in the absence of any personal contact. Moreover, our results support the crucial effect of identification and identity for giving behavior.

4: People differ in their pro-social attitudes. The type of person (as partially reflected by the choice of study) influences donating even when standard personal characteristics (gender and age) are controlled for.

Our data suggest that students indeed select into different disciplines according to differences in their pro-social preferences.

5: Teachers have no influence on who does or does not donate. 
The empirical analysis indicates that economics students do not change their pro-social attitudes due to their economics training.

The results derived are based on the behavior of the students and a survey carried out at the University of Zurich. Future research must establish whether the giving behavior identified applies to other persons and to other settings. However, we are confident that our findings are not peculiar to these students but apply more generally. The students at the University of Zurich are quite unlike a student population in many other countries, especially the United States, because they are considerably older and a large number of them hold a part-time job while studying. They are thus more like the population at large than, for instance, American college students. 


\section{References}

Adam, J.S. (1963). Wage Inequalities, Productivity and Work Quality. Industrial Relations 3. 9-16.

Adam, J.S. (1965). Inequity in Social Exchange. In: L. Berkowitz (ed.). Advances in Experimental Social Psychology, vol. 2. New York: Academic Press.

Akerlof, George A. and Rachel E. Kranton (2000). Economics and Identity. Quarterly Journal of Economics 115(3). 715-53.

Alm, James, Gary McClelland and William D. Schulze (1992). Why Do People Pay Taxes?. Journal of Public Economics 48: 21-38.

Andreoni, James (1989). Giving with Impure Altruism: Applications to Charity and Ricardian Equivalence. Journal of Political Economy 97 (3). 1147-1158.

Andreoni, James (1990). Impure Altruism and Donations to Public Goods: A Theory of Warm-Glow Giving. Economic Journal 100. 464-477.

Andreoni, James (1992). Warm-Glow Versus Cold-Prickle: The Effects of Positive and Negative Framing on Cooperation in Experiments. Quarterly Journal of Economics 60 (1).1-21.

Andreoni, James (1998). Toward a Theory of Charitable Fund-Raising. Journal of Political Economy 106(6). 1186-1213.

Andreoni, James (2001). The Economics of Philanthropy. To appear in: N.J. Smelser and P.B. Baltes (eds.). The International Encyclopedia of the Social and Behavioral Sciences. London: Elsevier.

Andreoni, James, Brian Erard and Jonathan Feinstein (1998). Tax Compliance. Journal of Economic Literature 36(2). 818-60.

Andreoni, James and Lise Vesterlund (2001). Which Is the Fair Sex? Gender Differences in Altruism. Quarterly Journal of Economics 116(1). 293-312.

Becker, Gary S. (1974). A Theory of Social Interactions. Journal of Political Economy 82. 1063-1093.

Becker, Gary S. (1976). The Economic Approach to Human Behavior. Chicago/London: University of Chicago Press.

Becker, Gary S. (1996). The Economic Way of Looking at Behavior: the Nobel Lecture. Stanford University: Hoover Institution on War, Revolution and Peace.

Bohnet, Iris and Bruno S. Frey (1999). Social Distance an Other-Regarding Behavior in Dictator Games: Comment. American Economic Review 89(1). 335-339.

Bolton, Gary and Axel Ockenfels (2000). ERC - A Theory of Equity, Reciprocity and Competition. American Economic Review 90. 166-193.

Boulding, Kenneth (1973). The Economy of Love and Fear. Belmont, CA: Wadsworth.

Bowles, Samuel and Herbert Gintis (2001). Social Capital and Community Governance. Mimeo. Santa Fe Institute. 
Cadsby, Charles Bram and Elizabeth Maynes (1998). Choosing Between a Socially Efficient and Free-Riding Equilibrium: Nurses Versus Economics and Business Students. Journal of Economic Behavior and Organization 37. 603-620.

Carter, John R. and Michael D. Irons (1991), Are Economists Different, and If So, Why? Journal of Economic Perspectives 5, 171-177.

Clotfelter, Charles T. (1997). The Economics of Giving. In: Barry, John W. und Bruno V. Manno (Eds.). Giving Better, Giving Smarter. Washington, D.C.: National Commission on Philanthropy and Civic Renewal. 31-55.

Clotfelter, Charles T. (2001). Alumni Giving to Elite Private Colleges and Universities. Working Paper.

Collard, David (1978). Altruism and the Economy: A Study of Non-Selfish Economics. London: Martin Robertson.

Dawes, Robyn M., J. McTavish and H. Shaklee (1977), Behavior, Communication, and Assumptions About Other People's Behavior in a Commons Dilemma Situation, Journal of Personality and Social Psychology 35, 1-11.

Dawes, Robyn M. and Richard H. Thaler (1988). Cooperation. Journal of Economic Perspectives 2(3). 187-197.

Dufwenberg, Martin and Georg Kirchsteiger (1998). A Theory of Sequential Reciprocity. Mimeo. CentER for Economic Research. Tilburg.

Eckel, Catherine C. and Philip J. Grossman (1998). Are Women Less Selfish Than Men? Evidence From Dictator Experiments. Economic Journal 108. 726-735.

Eckel, Catherine C. and Philip J. Grossman (1996). Altruism in Anomymous Dictator Games. Games and Economic Behavior 16(2). 181-191.

Eichenberger, Reiner and Felix Oberholzer-Gee (1998), Rational Moralists: The Role of Fairness in Democratic Economic Politics, Public Choice 94, 191-210.

Elliott, Catherine S. and Donald M. Hayward (1998). The Expanding Definition of Framing and Its Particular Impact on Economic Experimentation. Journal of Socio-Economics 27(2). 229-243.

Falk, Armin and Urs Fischbacher (2001). A Theory of Reciprocity. CESifo Working Paper No. 457.

Fehr, Ernst and Klaus M. Schmidt (1999). A Theory of Fairness, Competition, and Cooperation. Quarterly Journal of Economics 114: 817-868.

Fehr, Ernst and Klaus M. Schmidt (2000). Fairness, Incentives, and Contractual Choices. European Economic Review 44 (4-6): 1057-68.

Fehr, Ernst and Simon Gächter (2000). Cooperation and Punishment in Public Goods Experiments. American Economic Review 20: 980-994.

Fischbacher, Urs, Simon Gächter and Ernst Fehr (2001). Are People Conditionally Cooperative? Evidence from a Public Goods Experiment. Economics Letters; 71(3): 397404. 
Foster, Vivien, Susana Mourato, David Pearce and Ece Özdemiroglu (2001). The Price of Virtue: The Economic Value of the Charitable Sector. Cheltenham U.K.: Edward Elgar Publishing.

Frank, Björn und Günther G. Schulze (2000). Does Economics Make Citizens Corrupt? Journal of Economic Behavior and Organization 43 (1). 101-113.

Frank, Robert H., Thomas Gilovich and Dennis T. Regan (1993). Does Studying Economics Inhibit Cooperation? Journal of Economic Perspectives 7, 159-171.

Frank, Robert H., Thomas Gilovich and Dennis T. Regan (1996). Do Economists Make Bad Citizens? Journal of Economic Perspectives 10, 187-192.

Freeman, Richard B. (1997). Working for Nothing: the Supply of Volunteer Labour. Journal of Labour Economics 15: 140-166.

Frey, Bruno S. (1999). Economics as a Science of Human Behaviour: Towards a New Social Science Paradigm. Boston et al.: Kluwer Academic Publishers.

Frey, Bruno S. (2001). Inspiring Economics: Human Motivation in Political Economy. Cheltenham: U.K. Edward Elgar Publishing.

Frey, Bruno S. and Iris Bohnet (1995). Institutions Affect Fairness: Experimental Investigations. Journal of Institutional and Theoretical Economics (JITE) 151(2). 286-303.

Frey, Bruno S. and Stephan Meier (2001). Are Political Economists Selfish and Indoctrinated? Institute of Empirical Economic Research, University of Zurich, Working Paper.

Frey, Bruno S., Werner W. Pommerehne and Beat Gygi (1993). Economics Indoctrination or Selection? Some Empirical Results, Journal of Economic Education 24, 271-281.

Gächter, Simon and Armin Falk (2001). Reputation and Reciprocity - Consequences for the Labour Relation. Scandinavian Journal of Economics. Forthcoming.

Glaeser, Edward L., David I. Laibson, José A. Scheinkman and Christine L. Soutter (2000). Measuring Trust. The Quarterly Journal of Economics 115(3). 811-846.

Godelier, Maurice (2000). Things You Don't Give or Sell but Which You Keep: Valuable and Social Objects. In: Gérard-Varet, Louis André, Serge-Christophe Kolm and Jean Mercier Ythier (eds.). The Economics of Reciprocity, Giving and Altruism. Houndmills et al.: MacMillan Press Ltd. 182-195.

Gouldner, Alvin Ward (1960). The Norm of Reciprocity: A Preliminary Statement. American Sociological Review 25: 161-178.

Graetz, Michael J. and Louis L. Wilde (1985). The Economics of Tax Compliance: Facts and Fantasy. National Tax Journal 38 (September): 355-363.

Henrich, Joseph et al. (2001). In Search of Homo Economicus: Behavioral Experiments in 15 Small-Scale Societies. American Economic Review 91: 73-78.

Hirshleifer, Jack (1985). The Expanding Domain of Economics. American Economic Review 75 (May): 53-68.

Hoffman, Elizabeth, Kevin McCabe and Vernon L. Smith (1996). Social Distance and OtherRegarding Behavior in Dictator Games. American Economic Review 86. 653-660. 
Hull, Brooks B. and Frederick Bold (1995). Preaching Matters: Replication and Extension. Journal of Economic Behavior and Organization 27 (1). 143-149.

Isaac, R.M., D. Mathieu and E.E. Zajac (1991). Institutional Framing and Perceptions of Fairness. Constitutional Political Economy 2. 329-370.

Jenni, Karen E. and George Loewenstein (1997). Explaining the 'Identifiable Victim Effect'. Journal of Risk and Uncertainty 14 (3). 235-257.

Johannesson, Magnus and Björn Persson (2000). Non-Reciprocal Altruism in Dictator Games. Economics Letters 69. 137-142.

Kelman, Steven (1987). "Public Choice" and Public Spirit. The Public Interest 87 (Spring). 80-94.

Keser, Claudia and Frans van Winden (2000). Conditional Cooperation and Voluntary Contributions to Public Goods. Scandinavian Journal of Economics 102(1). 23-39.

Kolm, Serge-Christophe (1973). La théorie de la réciprocité. Paris: CEPREMAP.

Kolm, Serge-Christophe (1984). La Bonne Economie: La Réciprocité Générale. Paris: Presses Universitaires de France.

Kolm, Serge-Christophe (2000a). Introduction: The Economics of Reciprocity, Giving and Altruism. In: Gérard-Varet, Louis André, Serge-Christophe Kolm and Jean Mercier Ythier (eds.). The Economics of Reciprocity, Giving and Altruism. Houndmills et al.: MacMillan Press Ltd. 1-44.

Kolm, Serge-Christophe (2000b). The Theory of Reciprocity. In: Gérard-Varet, Louis André, Serge-Christophe Kolm and Jean Mercier Ythier (eds.). The Economics of Reciprocity, Giving and Altruism. Houndmills et al.: MacMillan Press Ltd. 115-141.

Lazear, Edward P. (2000). Economic Imperialism. Quarterly Journal of Economics 115 (1). 99-146.

Ledyard, John O. (1995), Public Goods: A Survey of Experimental Research. In: John H. Kagel und Alvin E. Roth (Eds.). Handbook of Experimental Economics. Princeton: Princeton University Press, 111-194.

Levi, Margret (1988). Of Rule and Revenue. Berkeley: University of California Press.

Lindenberg, S. (1992). An Extended Theory of Institutions and Contractual Discipline. Journal of Institutional and Theoretical Economics 148. 125-154.

Lipford, Jody, Robert E. McCormick and Robert D. Tollison (1993). Preaching Matters. Journal of Economic Behavior and Organization 21 (3). 235-250.

Mael, Fred and Blake E. Ashforth (1992). Alumni and Their Alma Mater: A Partial Test of the Reformulated Model of Organizational Identification. Journal of Organizational Behavior 13. 103-123.

March, James G. and J.P. Olsen (1995). Democratic Governance. New York: Free Press.

Marwell Gerald and Ruth E. Ames (1981). Economists Free Ride, Does Anyone Else? Experiments on the Provision of Public Goods IV. Journal of Public Economics 15. 295 310.

Mauss, Marcel (1924). Essai sur le Don. Forme et Raison de L'Echange dans les Sociétés Archaïques. L'Année Sociologique 1. 30-186. 
Mueller, Dennis C. (1989). Public Choice II. Cambridge UK: Cambridge University Press, $2^{\text {nd }}$ ed.

Mueller, Dennis C. (ed.) (1997). Perspectives on Public Choice: A Handbook. Cambridge, New York and Melbourne: Cambridge University Press.

Ockenfels, Axel and Joachim Weimann (1999). Types and Patterns: An Experimental EastWest-German Comparison of Cooperation and Solidarity. Journal of Public Economics 71. 275-287.

Opp, Karl-Dieter (2001). Collective Political Action. Analyse \& Kritik 23(1). 1-20.

Ortmann, Andreas and Lisa K. Tichy (1999). Gender Differences in the Laboratory: Evidence from Prisoner's Dilemma Games. Journal of Economic Behavior and Organization 39. 32339.

Ostrom, Elinor (1998). A Behavioral Approach to the Rational Choice Theory of Collective Action. Presidential Address, American Political Science Association 1997. American Political Science Review 92 (1). 1-22.

Quattrone, G.A. and A. Tversky (1988). Contrasting Rational and Psychological Analysis of Political Choice. American Political Science Review 82 (3). 719-736.

Rabin, Matthew (1993). Incorporating Fairness into Game Theory and Economics. American Economic Review 81.1281-1302.

Ross, Lee, David Greene and Pamela House (1977). The 'False Consensus Effect': An Egocentric Bias in Social Perception and Attribution Processes. Journal of Experimental Social Psychology 13, 279-301.

Sahlins, Marshall (1970). The Spirit of the Gift: Une Explication de Texte. In: Echanges et Communications, Mélanges offerts à Claude Lévi-Strauss à l'occasion de son 60e anniversaire. Leiden: Mouton.

Schelling, Thomas C. (1968). The Life You Save May Be Your Own. In: S. Chase (ed.). Problems in Public Expenditure Analysis. Washington, DC: Brookings Institution. 127162.

Simon, Herbert (1993). Altruism and Economics. American Economic Review 83 (2). 156161.

Skinner, Jonathan and Joel Slemrod (1985). An Economic Perspective on Tax Evasion. National Tax Journal 38: 345-353.

Slemrod, Joel (ed.) (1992). Why People Pay Taxes. Tax Compliance and Enforcement. Ann Arbor: University of Michigan Press.

Sonnemans, Joep, Arthur Schram and Teo Offerman (1998). Public Good Provision and Public Bad Prevention: The Effect of Framing. Journal of Economic Behavior and Organization 34. 143-161.

Sonnemans, Joep, Arthur Schram and Theo Offerman (1999). Strategic Behavior in Public Good Games: When Partners Drift Apart. Economics Letters. 62(1): 35-41.

Stigler, George J. (1984). Economics - The Imperial Science? Scandinavian Journal of Economics 86: 301-313.

Sugden, Robert (1982). On the Economics of Philanthropy. Economic Journal 92. 341-350. 
Sugden, Robert (1984). Reciprocity: The Supply of Public Goods Through Voluntary Contributions. Economic Journal 94. 772-787.

Turner, John C. and Howard Giles (1981). Intergroup Behavior. Chicago: Chicago University Press.

Varese, Federico and Meir Yaish (2000). The Importance of Being Asked: The Rescue of Jews in Nazi Europe. Rationality and Society 12 (3): 307-334.

Weimann, Joachim (1994). Individual Behavior in a Free Riding Experiment. Journal of Public Economics 54. 185-200.

Weisbrod, Burton (1998). To Profit or Not to Profit. The Commercial Transformation of the Nonprofit Sector. Cambrige: Cambridge University Press. 
Table 1: Summary Statistics

\begin{tabular}{|c|c|c|c|}
\hline Variables & $\begin{array}{c}\text { Number of } \\
\text { Observations }\end{array}$ & $\begin{array}{l}\text { Percentage of } \\
\text { student body }\end{array}$ & $\begin{array}{c}\text { Percentage who contribute } \\
\text { to at least one Fund }\end{array}$ \\
\hline Economists & 13932 & 10.18 & 62.82 \\
\hline Non-Economists & 122930 & 89.82 & 69.26 \\
\hline Theology & 1367 & 1.00 & 77.18 \\
\hline Law & 21777 & 15.91 & 64.01 \\
\hline Medicine & 15211 & 11.11 & 65.81 \\
\hline Veterinary Medicine & 3760 & 2.75 & 58.46 \\
\hline Arts Faculty & 62086 & 45.36 & 73.13 \\
\hline Natural Science & 14524 & 10.61 & 66.99 \\
\hline Computer Science & 4205 & 3.07 & 66.87 \\
\hline Pre-university economic knowledge & 23944 & 17.49 & 65.83 \\
\hline Age, Mean (s.d.) & $27.78(7.97)$ & & \\
\hline Aged below 26 & 65563 & 47.90 & 71.09 \\
\hline Age $26-30$ & 37399 & 27.33 & 63.62 \\
\hline Age $31-35$ & 17673 & 12.91 & 65.70 \\
\hline Age $36-40$ & 8366 & 6.11 & 69.77 \\
\hline Aged over 40 & 7861 & 5.74 & 76.92 \\
\hline \multicolumn{4}{|l|}{ Gender } \\
\hline Women & 68468 & 50.03 & 69.16 \\
\hline Men & 68394 & 49.97 & 68.05 \\
\hline \multicolumn{4}{|l|}{ Nationality } \\
\hline Foreigner & 15782 & 11.53 & 62.91 \\
\hline Swiss & 121080 & 88.47 & 69.35 \\
\hline Number of semesters, Mean (s.d.) & $10.47(8.21)$ & & \\
\hline Period 1 (winter semester 1998/99) & 19507 & 14.25 & 64.15 \\
\hline Period 2 (summer semester 1999) & 18231 & 13.32 & 67.07 \\
\hline Period 3 (winter semester 1999/00) & 20060 & 14.66 & 69.06 \\
\hline Period 4 (summer semester 2000) & 18650 & 13.63 & 69.10 \\
\hline Period 5 (winter semester 2000/01) & 20335 & 14.86 & 70.24 \\
\hline Period 6 (summer semester 2001) & 19075 & 13.94 & 69.78 \\
\hline Period 7 (winter semester 2001/02) & 21004 & 15.35 & 70.56 \\
\hline
\end{tabular}

Data source: Compiled from data provided by the accounting department of the University of Zurich. 
Table 2: Contibution to two Social Funds, University of Zurich 1998-2001

\begin{tabular}{lll}
\hline \hline & Absolute & Percent \\
\hline Contribution to both Funds (\$7.2) & 84,765 & $61.9 \%$ \\
Contribution to Foreigner Fund only $(\$ 3)$ & 5949 & $4.35 \%$ \\
Contribution to Loan Fund only $(\$ 4.2)$ & 3184 & $2.33 \%$ \\
No contribution to either Funds & 42,964 & $31.39 \%$ \\
\hline Total & 136,862 & 100.00 \\
\hline \hline
\end{tabular}

Data source: Compiled from data provided by the accounting department of the University of Zurich.

Figure 1: Contributions depending on number of semesters

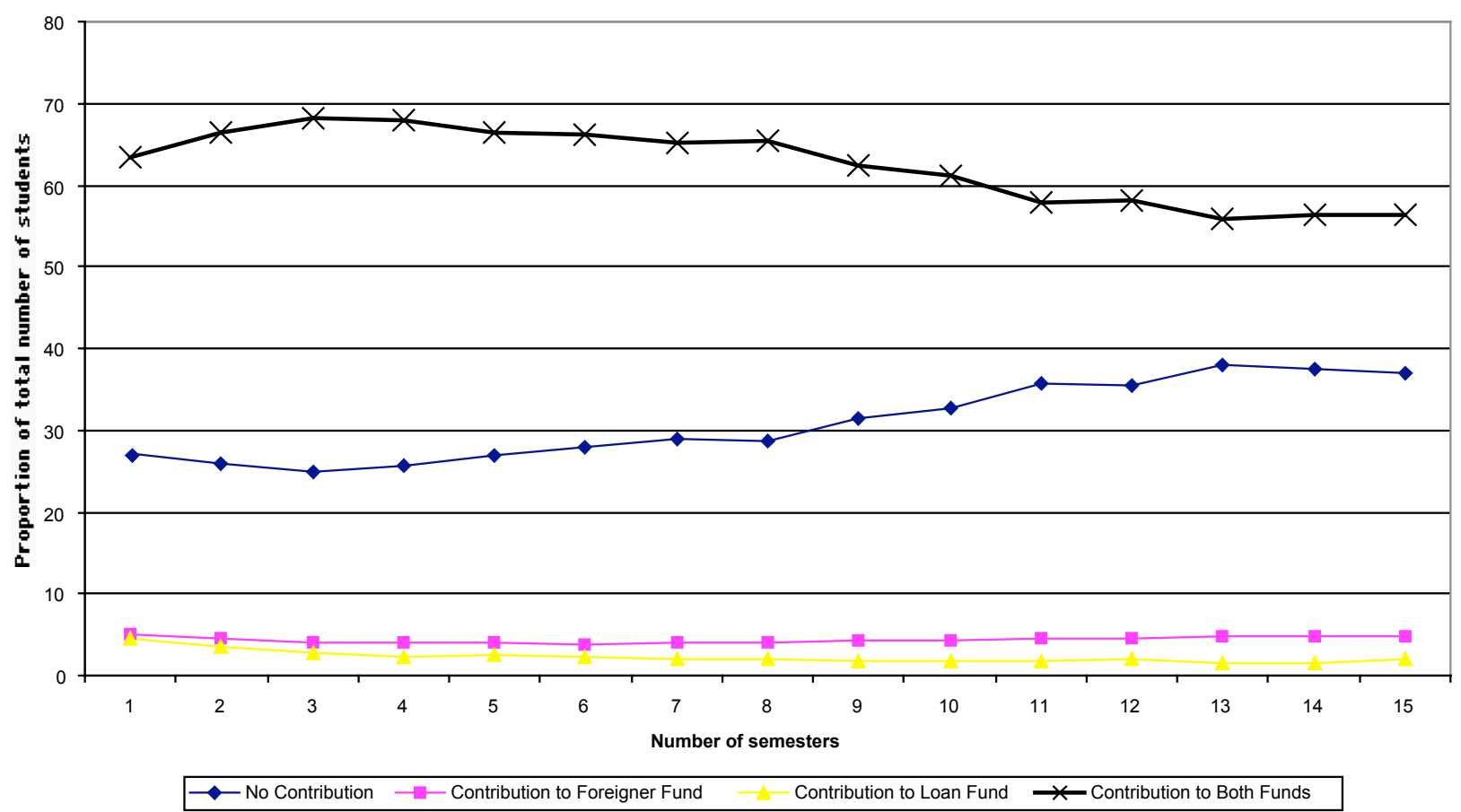

Notes: Students are shown up until their $15^{\text {th }}$ semester. Eight semesters, including the exams, is the norm. But $22 \%$ of the students study longer.

Data source: Compiled from data provided by the accounting department of the University of Zurich. 


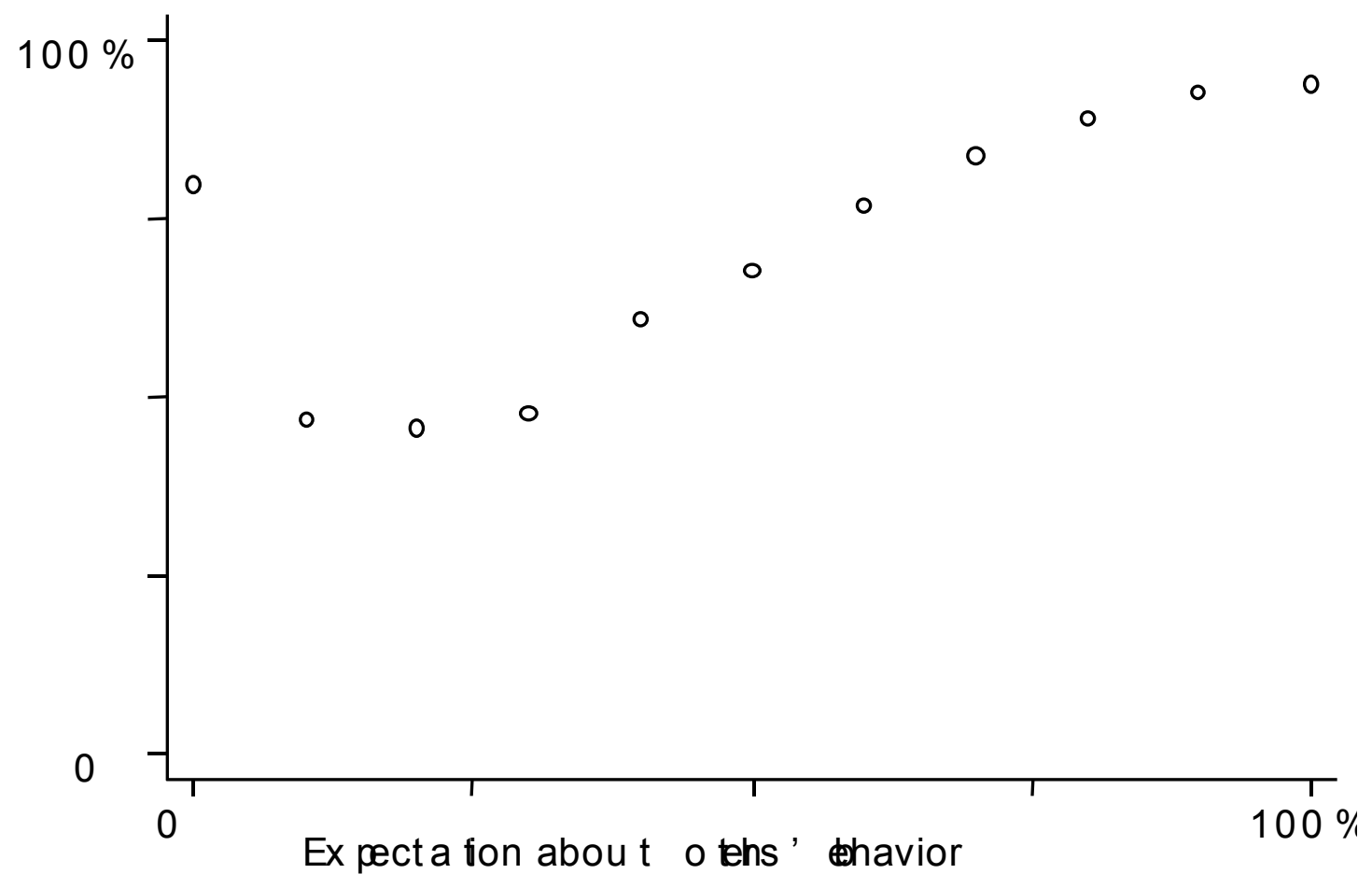

Figure 2: Exp ectat ions and Actual B havior 
Table 3: Knowledge about the Contribution of Others

- 'Do your friends know about your contribution?'

\begin{tabular}{lcc} 
& Absolute & Percent \\
\hline No, we do not know & 2568 & 78.87 \\
Yes, we do know & 688 & 21.13 \\
Total & 3256 & 100.00 \\
\hline
\end{tabular}

- 'Do you ever talk about the two Social Funds to your friends?'

\begin{tabular}{lcc} 
& Absolute & Percent \\
\hline No, we do not talk & 2488 & 76.34 \\
Yes, we do talk & 771 & 23.66 \\
Total & 3259 & 100.00 \\
\hline
\end{tabular}

Data source: Own survey 2000.

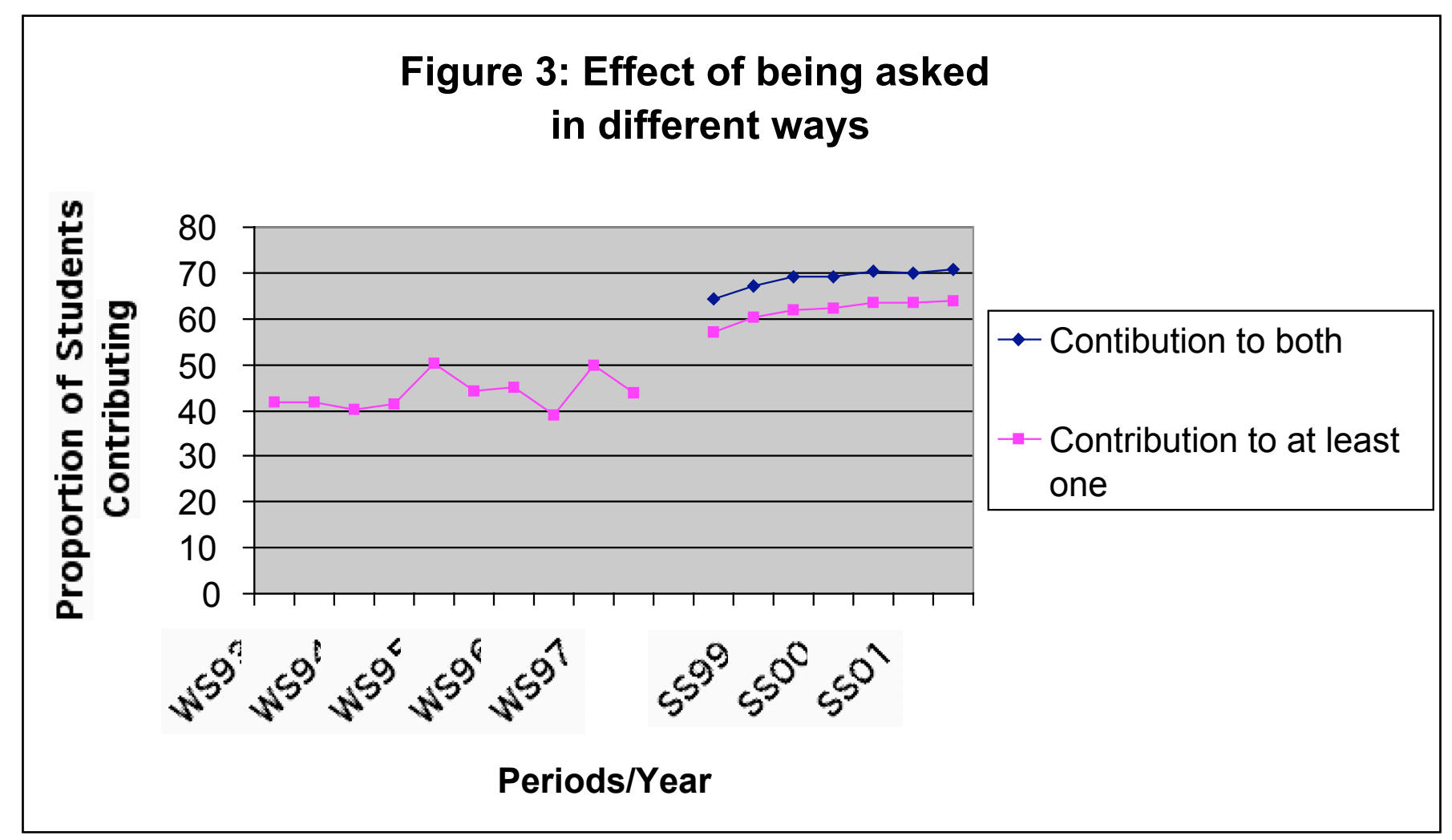


Table 4: Contribution to the Social Funds

University of Zurich 1998-2001

Dichotomous dependent variable: 'Contribution to at least one fund' $=1$

\begin{tabular}{|c|c|c|c|c|c|}
\hline \multirow[b]{2}{*}{ Variable } & \multicolumn{3}{|c|}{$\begin{array}{c}\text { Model I } \\
\text { Probit estimate } \\
\end{array}$} & \multicolumn{2}{|c|}{$\begin{array}{c}\text { Model II } \\
\text { Conditional fixed effect logit } \\
\end{array}$} \\
\hline & Coefficient & Z-value & $\begin{array}{l}\text { Marginal } \\
\text { effect }\end{array}$ & Coefficient & Z-value \\
\hline Freshmen & $-0.065 * *$ & -3.503 & $-2.3 \%$ & $-0.266^{* *}$ & -4.858 \\
\hline Main stage & $0.114 * *$ & 10.438 & $4.1 \%$ & -0.101 & -1.823 \\
\hline Ph.D. & 0.017 & 1.105 & $0.6 \%$ & -0.010 & -0.082 \\
\hline Last semester & $-0.184 * *$ & -14.692 & $-6.6 \%$ & $-0.189 * *$ & -4.327 \\
\hline Number of semesters & $-0.043^{* *}$ & -24.322 & $-1.5 \%$ & $-0.274 * *$ & -3.945 \\
\hline 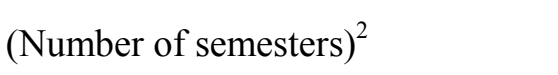 & $0.001 * *$ & 14.202 & $0.02 \%$ & -0.001 & -1.211 \\
\hline Age $26-30$ & 0.157 & 1.357 & $0.6 \%$ & -0.094 & -1.615 \\
\hline Age $31-35$ & $0.189 * *$ & 11.889 & $6.8 \%$ & 0.019 & 0.186 \\
\hline Age $36-40$ & $0.347 * *$ & 16.457 & $12.4 \%$ & 0.087 & 0.608 \\
\hline Age over 40 & $0.541 * *$ & 23.050 & $19.4 \%$ & 0.174 & 0.642 \\
\hline Gender $($ female $=1)$ & -0.012 & -1.497 & $-0.4 \%$ & & \\
\hline Nationality (foreigner=1) & $-0.103^{* *}$ & -8.544 & $-3.7 \%$ & & \\
\hline Married (=1) & $0.052 * *$ & 3.780 & $1.9 \%$ & 0.210 & 1.404 \\
\hline Period 2 (summer semester 1999) & $0.082 * *$ & 6.030 & $2.9 \%$ & $0.479 * *$ & 6.247 \\
\hline Period 3 (winter semester 1999/00) & $0.142 * *$ & 10.810 & $5.1 \%$ & $0.816^{* *}$ & 5.874 \\
\hline Period 4 (summer semester 2000) & $0.141 * *$ & 10.440 & $5.1 \%$ & $0.977 * *$ & 4.749 \\
\hline Period 5 (winter semester 2000/01) & $0.179 * *$ & 13.567 & $6.4 \%$ & $1.229 * *$ & 4.529 \\
\hline Period 6 (summer semester 2001) & $0.168 * *$ & 12.456 & $6.0 \%$ & $1.360 * *$ & 4.008 \\
\hline Constant & $0.606^{* *}$ & 41.282 & & & \\
\hline $\mathrm{N}$ & $115^{\prime} 858$ & & & 39,583 & \\
\hline \multirow[t]{2}{*}{ Log Likelihood } & \multirow[t]{2}{*}{-71041.783} & & & \multicolumn{2}{|l|}{-14811.858} \\
\hline & & & & \multicolumn{2}{|c|}{$\operatorname{LR}_{\operatorname{chi}^{2}}(16)=180.09$} \\
\hline
\end{tabular}

\begin{aligned} \hline \hline Notes: & Reference group consists of 'non-economists', 'basic study', 'without pre-university economic knowledge', 'aged \\ & below 26', 'male', 'Swiss', 'semester 1998/99'. \end{aligned}

Level of significance: ${ }^{*} 0.01<\mathrm{p}<0.05, * * \mathrm{p}<0.01$

Data source: Compiled from data provided by the accounting department of the University of Zurich. 
Table 5: Contribution of Swiss and Foreigners to the Two Social Funds

University of Zurich 1998-2001

\begin{tabular}{lccc}
\hline \hline & Swiss & Foreigners & Total \\
\hline Contribution to both Funds $(\$ 7.2)$ & $63.28 \%$ & $51.60 \%$ & $61.93 \%$ \\
& $(\mathrm{~N}=76622)$ & $(8143)$ & $(84765)$ \\
Only to Foreigner Fund $(\$ 3)$ & $3.61 \%$ & $9.97 \%$ & $4.35 \%$ \\
& $(4376)$ & $(1573)$ & $(5949)$ \\
Only to Loan Fund $(\$ 4.2)$ & $2.45 \%$ & $1.35 \%$ & $2.33 \%$ \\
& $(2971)$ & $(213)$ & $(3184)$ \\
No contribution to the Funds & $30.65 \%$ & $37.09 \%$ & $31.39 \%$ \\
& $(37111)$ & $(5853)$ & $(42964)$ \\
\hline Total & $100 \%$ & $100 \%$ & $100 \%$ \\
& $(121080)$ & $(15782)$ & $(136862)$ \\
\hline \hline
\end{tabular}

Notes: Pearson Chi2 (3)=1861.6411

Data source: Compiled from data provided by the accounting department of the University of Zurich. 
Table 6: Contribution of Students of Different Faculties in the First Semester

University of Zurich 1998-2001

Dichotomous dependent variable: 'Contribution to at least one fund' $=1$ Probit estimates

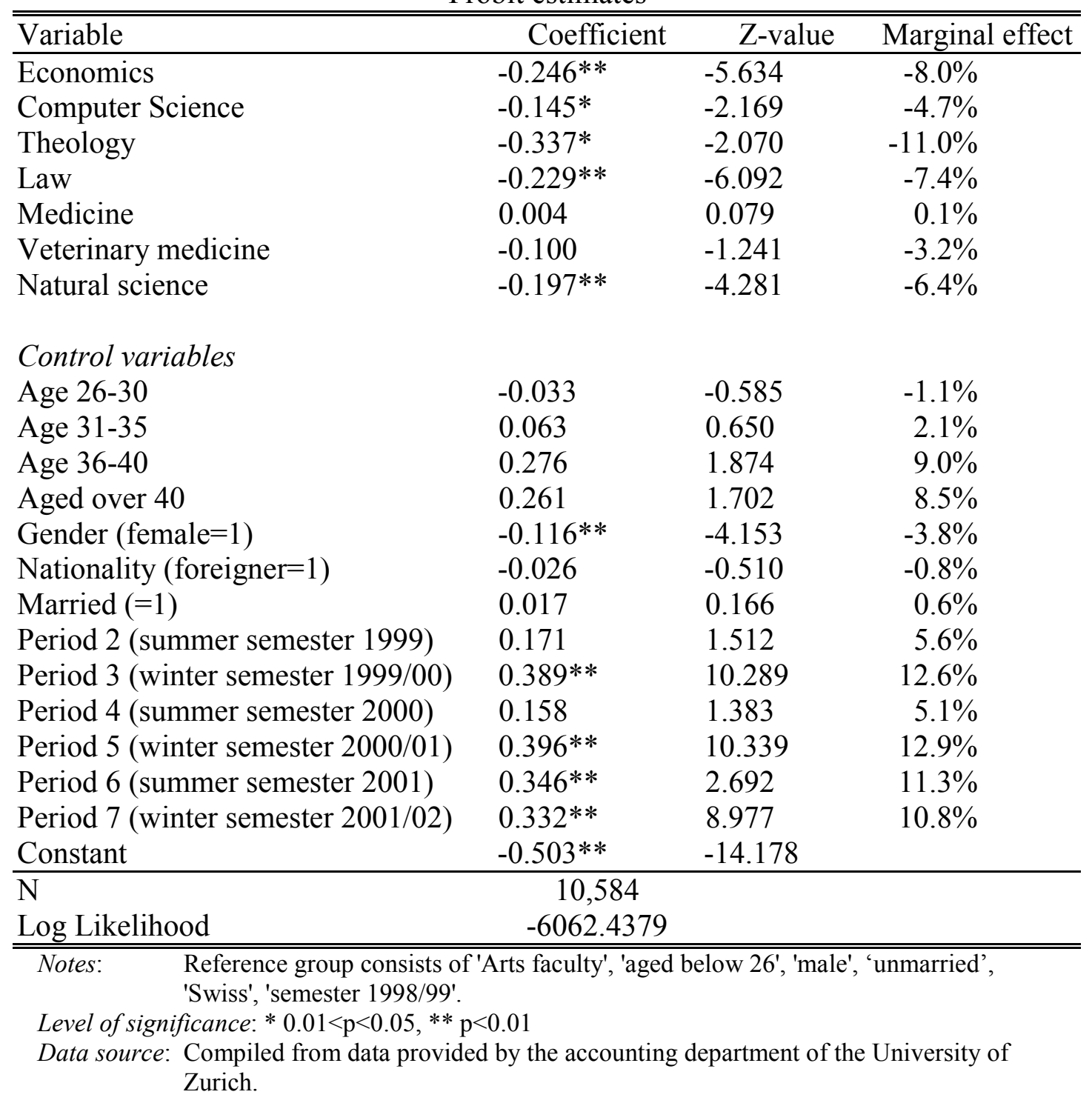




\section{Table 7: Indoctrination Effect of Different Faculties}

University of Zurich 1998-2001

Dichotomous dependent variable: 'Contribution to at least one fund' $=1$

Conditional fixed effects logit

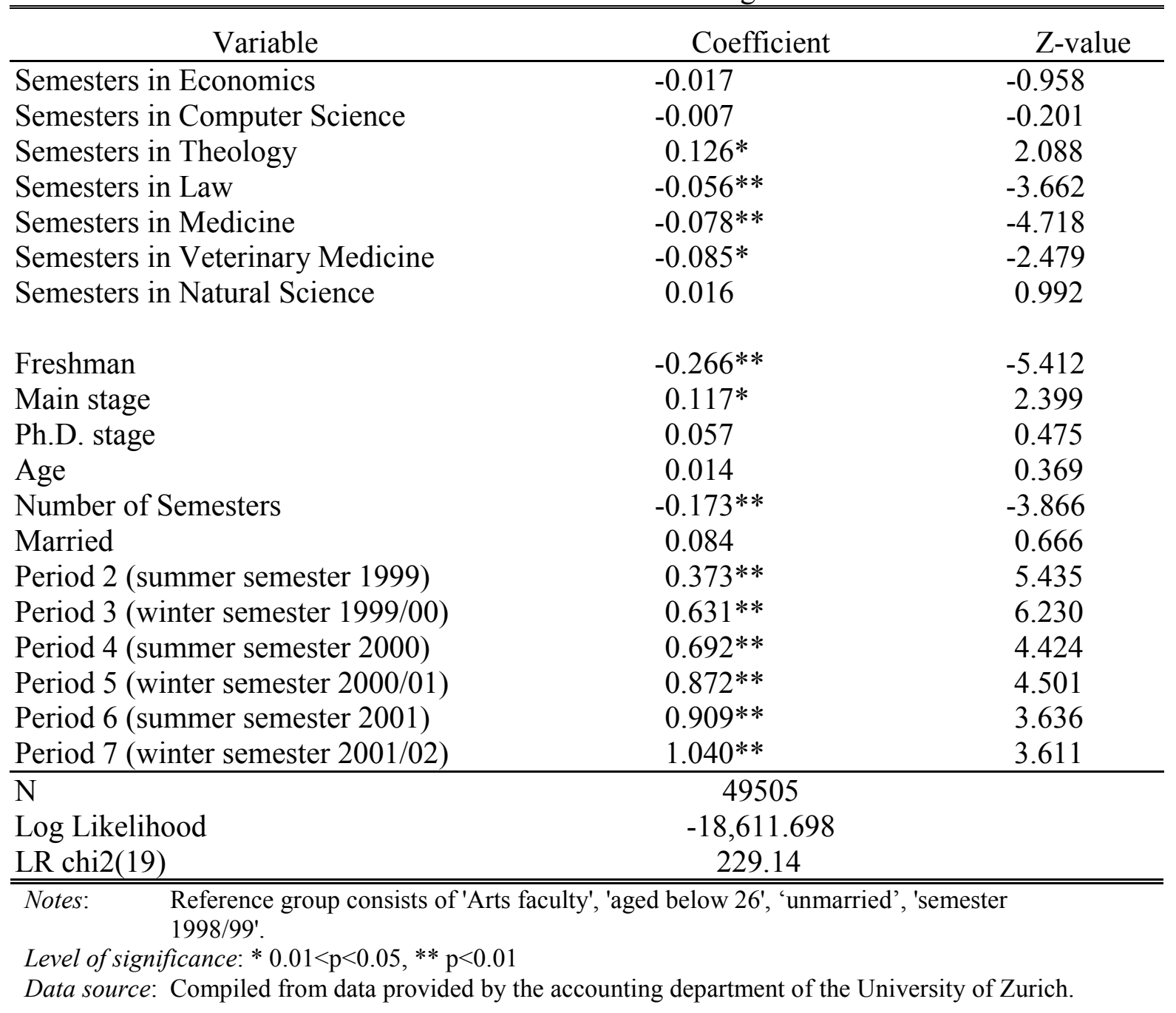

